\title{
BATS ASSOCIATED WITH INACTIVE MINES IN THE WESTERN GREAT BASIN
}

\author{
Michael L. Morrison ${ }^{1}$ and Sue Fox ${ }^{2}$
}

\begin{abstract}
We surveyed bats using echolocation calls near inactive mines in the western Great Basin from 2003 to 2007. We identified 14 species of bats during our surveys, with Myotis lucifugus and Lasionycteris noctivagans found at 9 sites and Myotis evotis and Tadarida brasiliensis at 7 sites; all other species were found at less than one-half of the sites. Euderma maculatum, a state-protected species in Nevada, was recorded at 2 sites. Our work provides information that will be useful in managing bat habitat, especially with regard to mining activities.
\end{abstract}

Key words: bats, California, echolocation calls, Great Basin, mining, Nevada.

Interest in the conservation of bats has grown as the impacts of habitat loss and disturbance at roost sites have increased (Kunz and Fenton 2003). Relative to other vertebrates, however, little is known about the distribution and abundance of bats or the limiting factors affecting bats. In particular, little data are available overall, and few recent studies have been conducted, on the distribution of bats in Nevada.

Hall (1946) first summarized the distribution of bats in Nevada, and Ports and Bradley (1996) provided information on bat ecology for eastern and northeastern Nevada. More recently, Kuenzi et al. (1999) identified 11 bat species during surveys at 18 water sources in west central Nevada. They identified 4 species-Myotis ciliolabrum, Myotis californicus, Pipistrellus hesperus, and Corynorhinus townsendii-as widely occurring. They also located 3 species hibernating in mine adits: $C$. townsendii, M. ciliolabrum, and P. hesperus. Although conducted for only one summer (1994), the Kuenzi et al. (1999) work provided one of the few focused studies of bats in western Nevada. Bradley et al. (2006) presented a conservation plan for Nevada's 23 bat species that assesses the state of bat conservation in Nevada and suggests proactive strategies for improving and standardizing the conservation of Nevada's bats.

As summarized by Bradley et al. (2006), disturbance and indiscriminate closure of abandoned mines is recognized as a threat to bats and their habitats. Because of present (2008) gold prices, exploration of abandoned mines and surrounding areas has increased. Our work was conducted largely in collaboration with state (Nevada Department of Wildlife) and private mine developers to determine the occurrence of bats in locations being considered for mine exploration. Our study provides additional data on bats in the western Great Basin, including specific information on the occurrence of bats using mining areas.

We sampled from 13 study areas that contained inactive mining projects. The study areas were located primarily within 4 vegetation types in the western Great Basin of Nevada and California (see Fig. 1 for location and details on each site): (1) The Mohave Desert vegetation occurs below $2000 \mathrm{~m}$ elevation and is characterized by several plant associations, primarily the mixed desert shrub community which includes shadscale (Atriplex confertifolia), Bailey's black greasewood (Sarcobates vermiculatus var. baileyi), budsage (Artemisia spinescens), Nevada ephedra (Ephedra nevadensis), and Joshua trees (Yucca brevifolia). (2) Sagebrush shrubland is characterized by big basin sagebrush (Artemisia tridentata ssp. tridentata), green ephedra (Ephedra viridis), rabbitbrush (Chrysothamnus sp.), spiny hopsage (Grayia spinosa), squirreltail (Sitanion hystrix), and Great Basin wild rye (Elymus cinereus). (3) Piñon-juniper woodland is characterized by piñon pine (Pinus monophylla), Utah juniper (Juniperus osteosperma), and understory

${ }^{1}$ Department of Wildlife and Fisheries Sciences, Texas A\&M University, College Station, TX 77843-2258. E-mail: mlmorrison@ag.tamu.edu

${ }^{2}$ Wildlife Resource Consultants, Box 68, Cedarville, CA 96104. 


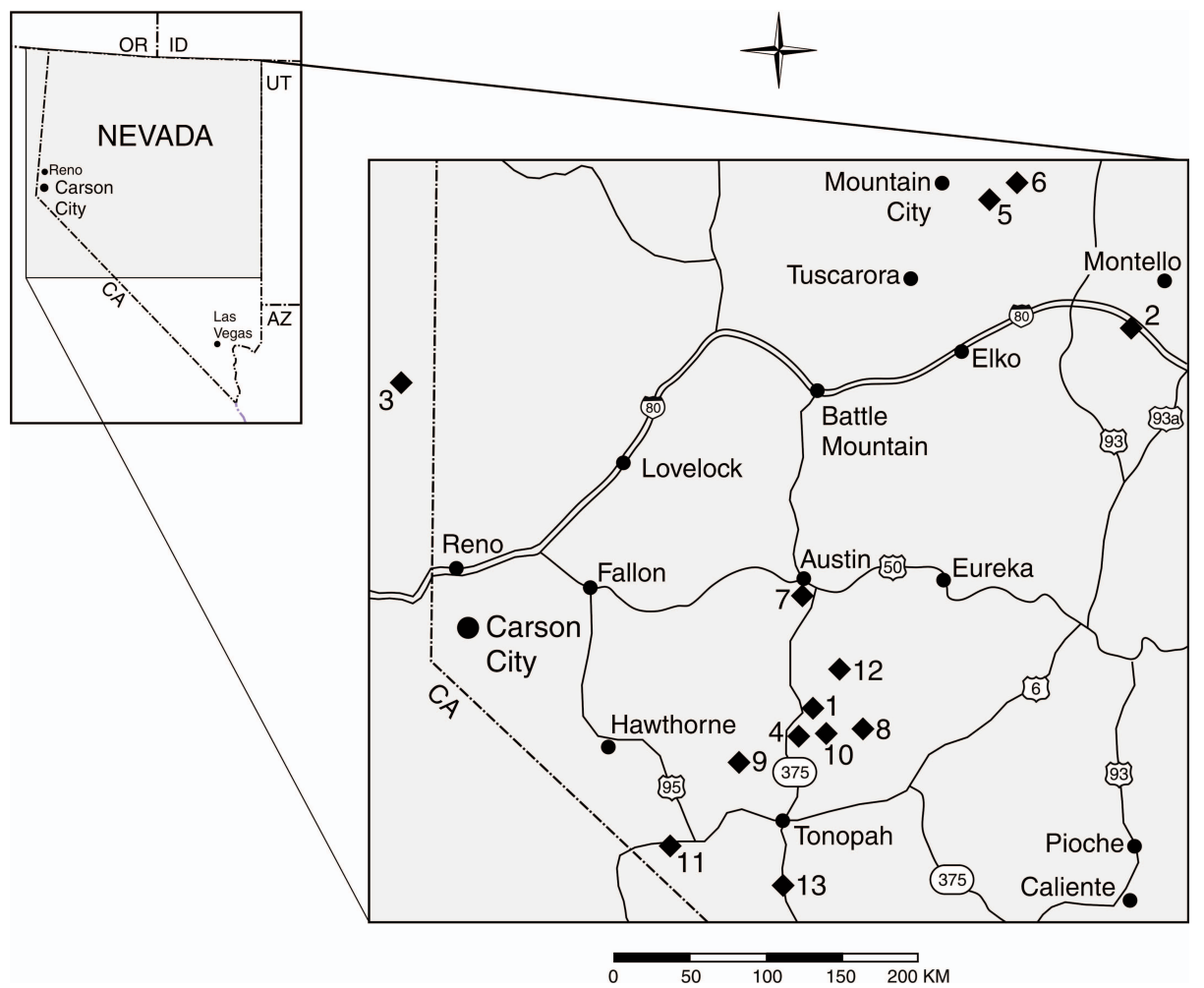

Fig. 1. Study locations $($ ) and dates for acoustic bat surveys, Nevada and eastern California. Site numbers are arbitrary and used to designate locations in Table 1.

1. Jefferson-Toquima Range, Nye County, Nevada; elevation $\sim 2500$ to $2700 \mathrm{~m}$. Surveyed 26-28 August and 7-8 September 2007. 2. Long Canyon-Pequop Mountains, Elko County, Nevada; elevation $\sim 2100$ to $2300 \mathrm{~m}$. Surveyed 1-6 September 2007. 3. Shaffer Mountain-Shaffer Mountain, Lassen County, California; elevation 1800 to $2300 \mathrm{~m}$. Surveyed May and June 2007. 4. Manhattan-Toquima Range, Nye County, Nevada; elevation $\sim 2500$ to $\sim 3000 \mathrm{~m}$. Surveyed June 2007. 5. St. Elmo-Humboldt-Toiyabe National Forest, Elko County, Nevada; elevation 2650 m. Surveyed July 2007. 6. Jarbidge-Humboldt-Toiyabe National Forest, Elko County, Nevada; elevation $\sim 2500$ to $\sim 4100 \mathrm{~m}$. Surveyed July 2006. 7. Birch Creek-Toiyabe Range, Lander County, Nevada; elevation $\sim 2700$ to $4200 \mathrm{~m}$. Surveyed July 2007. 8. House Canyon-Monitor Range, Nye County, Nevada; elevation $\sim 2600$ to $\sim 3900$ m. Surveyed 30 June and 1-2 July 2006. 9. Golden King-Shoshone Mountains, Nye County, Nevada; elevation $\sim 2300$ to $\sim 2500 \mathrm{~m}$. Surveyed June 2006. 10. Barcelona-Toquima Range, Nye County, Nevada; elevation $\sim 2900$ to $3100 \mathrm{~m}$. Surveyed June 2004. 11. Tip TopWhite Mountains, Esmeralda County, Nevada; elevation $\sim 2900$ to $\sim 3100$ m. Surveyed September 2003. 12. Northumberland/Toquimas-Toquima Range, Nye County, Nevada; elevation $\sim 2400$ to $2800 \mathrm{~m}$. Surveyed May and June 2004 . 13. Goldfield-Esmeralda County, Nevada, $\sim 1 \mathrm{~km} \mathrm{NE}$ of Goldfield; elevation 1800 to $2000 \mathrm{~m}$. Surveyed 4-9 May and 20-23 May 2004.

components of the sagebrush shrubland vegetation type. (4) Piñon woodland is characterized by piñon pine and understory components of the sagebrush shrubland vegetation type. Sampling locations were not chosen randomly but were sampled primarily as part of contractual arrangements with private companies operating on public lands.

Characteristics of echolocation calls can be used to distinguish between even closely related species, and several detector systems are commercially available (see O'Farrell et al. 1999, Szewczak 2004, Weller et al. 2007).
When intraspecific variation in call characteristics is large relative to interspecific variation, however, separation of some species can be problematic, especially when only a few call samples are available (Weller et al. 2007). We used echolocation calls to identify species of bats around mine adits and shafts, and water (usually ponds) near mines that could attract bats. Bats were not captured because of logistical constraints. Although capturing bats can aid in separation of closely related species (e.g., Myotis spp.), inventory of bats based on echolocation calls often results in a more thorough 
TABLE 1. Occurrence of bats during acoustic surveys in Nevada and eastern California, 2003-2007. Location codes are given in Fig. 1.

\begin{tabular}{lcl}
\hline Species & $\begin{array}{c}\text { Locations } \\
\text { present }(\%)\end{array}$ & Location code \\
\hline Myotis californicus & 31 & $3-5,11$ \\
Myotis ciliolabrum & 23 & $8,10,13$ \\
Myotis evotis & 54 & $1,2,5-7,10,12$ \\
Myotis lucifugus & 69 & $1-5,6-8,12$ \\
Myotis volans & 23 & $5,6,12$ \\
Myotis thysanodes & 31 & $2,5,6,13$ \\
Myotis yumanensis & 31 & $3,6,11,13$ \\
Lasionycteris noctivagans & 69 & $1-7,9,13$ \\
Lasiurus cinereus & 23 & $2,12,13$ \\
Eptesicus fuscus & 31 & $6,8,12,13$ \\
Pipistrellus hesperus & 46 & $3,4,6,8,12,13$ \\
Corynorhinus townsendii & 38 & $5,6,10,11,13$ \\
Euderma maculatum & 15 & 1,6 \\
Tadarida brasiliensis & 54 & $1-3,10-13$ \\
\hline
\end{tabular}

analysis of the bat assemblage relative to netting alone (e.g., Kuenzi and Morrison 1998).

We recorded bat echolocation calls using time-expansion detectors (Pettersson D240x, Pettersson Elektronik, Uppsala, Sweden) connected to analog cassette recorders (Sony TCM200DV). We placed a single detector-recorder combination at an adit or shaft entrance, or along the edge of ponds near the mines. We placed each detector-recorder within about 5 $\mathrm{m}$ (usually 1-2 $\mathrm{m}$ ) of the mine's entrance or water's edge and attached them either to existing structures or to a post we pounded into the ground. Each detector-recorder was started near sunset and allowed to run throughout the night.

Echolocation calls were downloaded and analyzed using SonoBat software (DNDesign, Arcata, CA). Recorded calls were compared to reference calls available within the SonoBat software. We assigned a quality rating of "good" or "poor" to each call sequence. Good call sequences contained $>1$ and usually many $(>10)$ calls in which the signal was clearly distinguishable from noise, appeared fully formed (i.e., no missing call components), and, in many cases, displayed harmonics that indicated calls had been well recorded (Weller et al. 2007). Poor-quality recordings had poor signal-tonoise ratios and were of short duration $(<2.5$ $\mathrm{ms}$ ), reduced bandwidth, or oversimplified shapes (Weller et al. 2007). We used the analysis tool within SonoBat to manually place cursors on a time-frequency sonogram of calls that indicated the location of the lowest frequency and the characteristic frequency. We only report results of good-quality calls for which we have high confidence of correct identification.

Detections of echolocation calls cannot be directly translated into count estimates because we cannot know the number of individuals passing the detector relative to the number of calls produced (i.e., 1 bat passing 10 times or 10 bats passing 1 time). Echolocations do, however, provide an index of bat activity, and an index can be used as a measure of the relative difference in activity between recording locations (Kuenzi and Morrison 2003). Therefore, we used the total number of bat passages during a recording session (i.e., 1 recorder for 1 night) as an index of bat activity. We defined a pass as a sequence of a bat's echolocation calls on the detector from beginning to end (Kuenzi and Morrison 2003). We did not enter shafts and adits during this study. We sampled on 50 nights during May-September from 2003 to 2007; all sites had approximately the same sampling effort.

We identified 14 species of bats during our surveys (Table 1). We recorded the highest number of species at Jarbidge (10 species), Goldfield (9), and St. Elmo (7). We recorded 6 species each at Long Canyon and Shaffer Mountain and 5 species at Jefferson; all other sites had 3-4 species except Caldera, which had only 1 species.

We found Myotis lucifugus and Lasionycteris noctivagans at 9 sites; they were also the most frequently recorded species at most sites. We found Myotis evotis and Tadarida brasiliensis at 7 sites; all other species were found at less than one-half of the sites. We found Pipistrellus hesperus at 6 sites, and this species was usually frequently recorded when present.

We recorded Euderma maculatum at Jarbidge and Jefferson (Table 1); although we made several recordings at each site, the species was apparently not abundant. We recorded $C$. townsendii at 5 sites; this species did not appear to be abundant anywhere.

Most of our sampling areas had multiple species of bats, with 6 areas having 6-10 species present. Although we cannot confirm that bats actually entered the adits and shafts we sampled, based on the close proximity of our recording equipment to mine entrances it is likely that many bats entered the mines. Trapping and thorough surveys of mine interiors 
would be needed to determine if these mines serve as roosting and breeding locations.

Except for E. maculatum and Lasiurus cinereus, all other species we recorded are widely distributed in Nevada, although several species are apparently declining in abundance (Bradley et al. 2006). Euderma maculatum was known from only 12 localities but has a scattered distribution throughout Nevada; it is state protected and is further classified as "threatened" in Nevada (Bradley et al. 2006). The Idaho portion of the Bruneau-Jarbidge River area appears to be an important population center for E. maculatum (Bradley et al. 2006), which likely explains the presence of this species at our Jarbidge study site. We located L. cinereus at 3 sites. Lasiurus cinereus has a patchy distribution in Nevada and is usually located through the capture of single animals or recordings (Bradley et al. 2006), which agrees with our recording only a few individuals at any site. Although most Nevada state records for $L$. cinereus are during spring, we sampled this species in both spring and fall.

Corynorhinus townsendii is a former category 2 candidate for federal listing as threatened and endangered and is a Nevada sensitive species (Bradley et al. 2006); the species has undergone serious population declines in the past 40 years in parts of the western United States (Pierson and Rainey 1996 in Bradley et al. 2006:18). We detected C. townsendii at 5 sites, but it was infrequently encountered. Because this species has low-amplitude calls, it is possible that our survey underestimated occurrence and activity. Corynorhinus townsendii is widely distributed in the western Great Basin during winter and uses mine adits and shafts for hibernacula (Szewczak et al. 1998). Additional research (e.g., banding) would be needed to determine if $C$. townsendii is resident in the areas we surveyed.

Myotis ciliolabrum is widely distributed and common in Nevada (Bradley et al. 2006). Our recordings of $M$. ciliolabrum at only 3 sites is thus surprising. We think, however, that our sites were generally above the elevation most frequented by this species in the northern parts of Nevada (Bradley et al. 2006). Because of overlapping characteristics in the sonograms for Myotis californicus and $M$. yumanensis, we recommend that additional work (i.e., netting) be conducted at sites where we recorded these species.
We recommend that additional intensive surveys be conducted at mines in the western Great Basin to help clarify the seasonal status of bat species. Of primary importance would be to thoroughly assess how species such as Euderma maculatum are using mines. Our work, however, provides information that will be useful in managing bat habitat, especially with regard to mining activities.

We thank the Nevada Department of Wildlife, the United States Forest Service, and the Bureau of Land Management for assisting with site access. J.M. Szewczak (Humboldt State University) assisted with identification of sonograms. We thank the anonymous referees and the journal editorial staff for improving this presentation.

\section{Literature Cited}

Bradley, P.V., M.J. O’Farrell, J.A. Williams, and J.E. NEwMark, EDIToRs. 2006. The revised Nevada Bat Conservation Plan. Nevada Bat Working Group, Reno, NV.

HaLL, E.R. 1946. Mammals of Nevada. University of California Press, Berkeley.

Kuenzi, A.J., G.T. Downard, and M.L. Morrison. 1999. Bat distribution and hibernacula use in west central Nevada. Great Basin Naturalist 59:213-220.

Kuenzi, A.J., AND M.L. MorRison. 1998. Detection of bats by mist-nets and ultrasonic sensors. Wildlife Society Bulletin 26:307-311. 2003. Temporal patterns of bat activity in southern Arizona. Journal of Wildlife Management 67:52-64.

KunZ, T.H., AND M.B. Fenton, EDITORs. 2003. Bat ecology. University of Chicago Press, Chicago, IL.

O’Farrell, M.J., B.W. Miller, and W.L. Gannon. 1999. Qualitative identification of free-flying bats using the Anabat detector. Journal of Mammalogy 80:11-23.

PorTs, M.A., AND P.V. BRADLEY. 1996. Habitat affinities of bats from northeastern Nevada. Great Basin Naturalist 56:48-53.

SZEWCZAK, J.M. 2004. Advanced analysis techniques for identifying bat species. Pages 121-127 in R.M. Brigham, E.K.V. Kalko, G. Jones, S. Parsons, and H.J.G.A. Limpens, editors, Bat echolocation research: tools, techniques, and analysis. Bat Conservation International, Austin, TX.

SzewCZaK, J.M., S.M. SzewCZaK, M.L. Morrison, and L.S. HaLL. 1998. Bats of the White and Inyo mountains of California-Nevada. Great Basin Naturalist 58:66-75.

Weller, T.J., S.A. Scott, T.J. Rodhouse, P.C. Ormsbee, AND J.M. ZINCK. 2007. Field identification of the cryptic vespertilionid bats, Myotis lucifugus and $M$. yumanensis. Acta Chiropterologica 9:133-147.

Received 26 January 2008 Accepted 11 September 2008 